\title{
Serum folates in young dairy heifers*
}

\author{
BY CHRISTIANE L. GIRARD, J. JACQUES MATTE \\ AND GABRIEL L. ROY \\ Agriculture Canada Research Station, Lennoxville, Quebec JIM 1Z3, Canada
}

(Received 18 February 1988 - Accepted 18 November 1988)

\begin{abstract}
1. In the first trial, hourly blood samples were drawn during the light period (06.30 20.30 hours) from thirtyfour dairy heifers in two groups of different ages.

2. Concentrations of serum folates were $8.2(\mathrm{SE} 0 \cdot 1) \mathrm{ng} / \mathrm{ml}$ at the age of $18 \cdot 2(\mathrm{SE} 0.6) \mathrm{d}$ and $14.8(\mathrm{SE} 0.2) \mathrm{ng} / \mathrm{ml}$ at $120.7(\mathrm{SE} 2.9) \mathrm{d}(P \leqslant 0.001)$.

3. In the second trial, forty heifers were randomly assigned to a factorial experiment where age ( 2 weeks $v$. 4 months) and quantity of pteroylmonoglutamic acid injected intramuscularly $(2 \cdot 5,5 \cdot 0,10 \cdot 0$ and $20 \cdot 0 \mathrm{mg})$ were the two factors studied. Blood samples were taken immediately before injection and on days 1, 2, 3, 4, 7 and 10 after the injection.

4. Serum folates reached a maximum on day 1 after the injection of pteroylmonoglutamic acid. The response to the injection was different for the two age groups $(P \leqslant 0.0002)$; concentration of serum folates for 2-week-old heifers markedly increásed, while in 4-month-old heifers the effect of a supplement of pteroylmonoglutamic acid was less marked.

5. These results might indicate a need for pteroylmonoglutamic acid in young animals during the development of rumen function.
\end{abstract}

The ruminant is generally considered not to need an exogenous supply of folates; synthesis of folates by rumen micro-organisms makes their inclusion in the diet unnecessary (National Research Council, 1978; Agricultural Research Council, 1980). However, a doubt persists about the efficiency of vitamin synthesis by rumen microflora during weaning and afterwards, during the stabilization of rumen function (Kon \& Porter, 1954; Mornet \& Espinasse, 1977; National Research Council, 1978; Roy, 1980).

Fluctuations in serum concentrations of folates during the first months of life of young ruminants may be an indication that synthesis of folates by rumen flora is not sufficient to meet requirements during weaning. In the first trial, the concentrations of serum folates in two groups of dairy heifers, one aged 2 weeks and the other aged 4 months, were compared. Concentrations of serum folates were also determined every hour during the light period of the day to determine if serum concentrations were affected by the nature of the diet or time of the meal. In a second trial, one intramuscular injection of pteroylmonoglutamic acid was given to increase the concentration of serum folates and examine the time response curves after administration.

\section{MATERIALS AND METHODS}

\section{Trial 1}

Animals. Thirty-four heifers from the dairy herd of the Agriculture Canada Research Station at Lennoxville were randomly assigned to seventeen blocks of two animals each; one group of animals had a mean age of 18.2 (SE 0.6) d and the other 120.7 (SE 2.9) d. Each block represented $1 \mathrm{~d}$ of sampling. The animals were housed together under $14 \mathrm{~h}$ of light (06.30-20.30 hours). The younger heifers were in individual pens with concrete floors and wood shavings. They received whole milk, collected during milking, at a rate of $10 \%$ of their body-weight, twice daily at 07.15 and 16.15 hours. They had free access to concentrates containing (per kg): $160 \mathrm{~g}$ crude protein (nitrogen $\times 6.25$; minimum), $22.5 \mathrm{~g}$

* Contribution no. 237 of the Agriculture Canada Research Station, Lennoxville. 
crude fat (minimum), $70 \mathrm{~g}$ crude fibre (maximum), $4 \mathrm{~g}$ sodium, $8 \mathrm{~g}$ calcium, $6.5 \mathrm{~g}$ phosphorus, $2.0 \mathrm{~g}$ magnesium, $300 \mathrm{mg}$ iron, $6 \mathrm{mg}$ iodine, $100 \mathrm{mg}$ zinc, $7.9 \mathrm{mg}$ vitamin $\mathrm{A}$, $0.09 \mathrm{mg}$ vitamin $\mathrm{D}_{3}, 0.15 \mathrm{mg}$ selenium (Nutribec, Quebec). The older heifers were penned in groups of three animals of similar age and were also kept on concrete floors with wood shavings. Concentrates $(1 \mathrm{~kg})$ were offered twice daily at 07.30 and 13.30 hours. Dry hay was given in the morning and hay silage offered ad lib at 13.00 hours. All heifers had free access to water. The animals were weighed the day before blood sampling began.

Blood sampling. Blood samples from the jugular vein were taken every hour during the light period of the day (fifteen samples per animal). The blood was allowed to clot at $4^{\circ}$ in the dark for $8-12 \mathrm{~h}$. The serum was separated by centrifugation at $3000 \mathrm{~g}$ for $10 \mathrm{~min}$, transferred into polypropylene tubes and stored at $-20^{\circ}$ until assayed.

Determination of folates. Serum folates were measured in duplicate by radioassay with a commercial kit adapted for human serum (Quantaphase Folate, Bio-Rad Laboratories (Canada) Ltd, Mississauga, Ontario). To ascertain that the folates standard would apply to bovine serum, radioactive pteroylmonoglutamic acid was added to sera collected from different heifers and run as a non-specific binding sample. The radioactivity counts for these bovine serum blanks were similar to those registered with the blanks routinely used in the procedure applied to human serum. Parallelism was good between 1 and $20 \mathrm{ng} / \mathrm{ml}$ and recovery tests with bovine serum were $103 \%$. The mean coefficient of variation between duplicates made in two different assays was 3.52. In view of these observations, it was concluded that this commercial kit could be safely used to analyse bovine serum.

Statistical analysis. Values were analysed as a completely random split block design (LeClercg et al. 1966) using the General Linear Model of the Statistical Analysis System (SAS, 1985). Analysis of repeated measurements was made according to Gill \& Hafs (1971). The following model was used:

$$
Y_{i j k}=\mu+B_{i}+A_{j}+B A_{i j}+T_{k}+A T_{j k}+e_{i j k},
$$

where $Y$ indicates the dependent variable, serum folates, the overall mean is $\mu, B_{i}$ is the block effect (day of sampling), $A_{j}$ is the age effect and $T_{k}$ the effect of time during the day. Least square means were compared using orthogonal contrasts when appropriate (Snedecor \& Cochran, 1971).

\section{Trial 2}

Animals. Forty heifers were randomly assigned to a factorial experiment where age (16.8 (SE 0.8) d v. 126.6 (SE 3.9) d) and level of supplementation of pteroylmonoglutamic acid $(2.5,5 \cdot 0,10 \cdot 0$ and $20.0 \mathrm{mg})$ were the two factors studied. Housing conditions and feeding were the same as in trial 1 . All heifers were weighed at the beginning and at the end of the trial.

Pteroylmonoglutamic acid administration. Each animal received on day 0 , only one intramuscular injection of pteroylmonoglutamic acid administered as a solution (Folvite ${ }^{\mathbb{R}}$; Lederle, Cyanamid Canada Inc, Montreal, Quebec) containing $5 \mathrm{mg}$ pteroylmonoglutamic acid $/ \mathrm{ml}$.

Blood sampling and determination of folates. Blood samples from the jugular vein were taken from each animal immediately before injection and then 1, 2, 3, 4, 7 and $10 \mathrm{~d}$ after the injection. Samples taken on days 0 and 10 were used for determination of haemoglobin and packed cell volume. The procedure for blood collection, serum storage and folates determination was as described for trial 1.

Statistical analysis. Values were analysed as a completely random design using the General Linear Model of the Statistical Analysis System (SAS, 1985). The following model was used:

$$
Y_{i j k}=\mu+A_{i}+D_{j}+A D_{i j}+T_{k}+A T_{i k}+D T_{j k}+A D T_{i j k}+e_{i j k},
$$




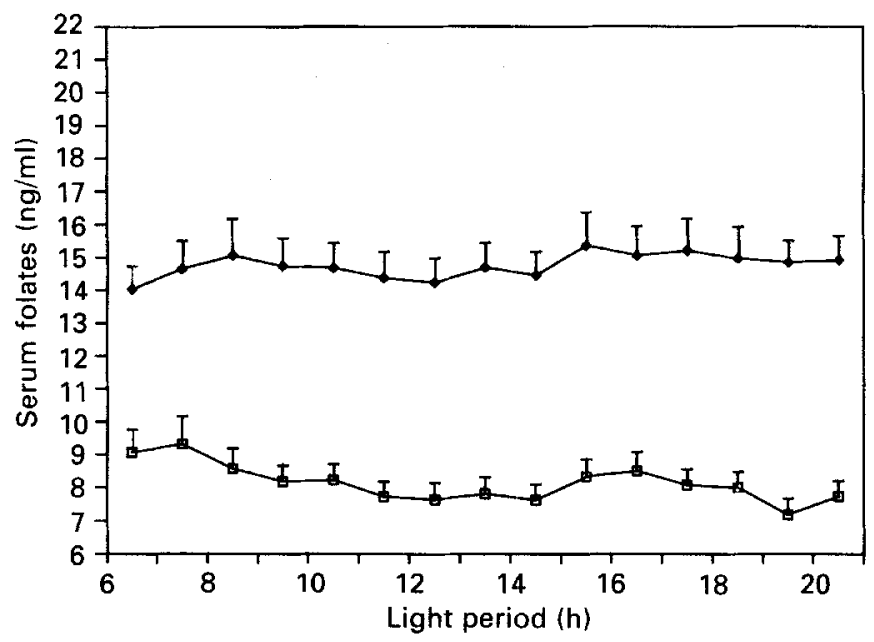

Fig. 1. Trial 1. Concentration of serum folates of heifers aged 2 weeks ( $\square$ ) and 4 months $(\diamond)$ during a $14 \mathrm{~h}$ light period. For details of procedures, see p. 595.

where $Y_{i j k}$ indicates the dependent variable, serum folates, the overall mean is $\mu, A_{i}$ is the effect of age, $D_{j}$ is the effect of dose injected and $T_{k}$ the effect of time following the injection. According to Cox (1980), the time response curves following the injection were divided in two parts: $0-1 \mathrm{~d}$ post-injection and $1-10 \mathrm{~d}$ post-injection. The effects of doses, time and their interactions on concentrations of serum folates were split into linear, quadratic and other effects by orthogonal contrasts when appropriate (Snedecor \& Cochran, 1971). The analysis of repeated measurements were made according to Gill \& Hafs (1971). A Bonferroni $t$ test was applied to determine the level of significance of time and timeinteractions because the time intervals between blood samples were different (Gill, 1978).

\section{RESULTS}

Trial 1

The mean body-weights were 45.9 (SE 1.3) $\mathrm{kg}$ for the younger heifers and 116.2 (SE 5.3) $\mathrm{kg}$ for the older ones. The concentration of serum folates was $8.2(\mathrm{SE} 0 \cdot 1) \mathrm{ng} / \mathrm{ml}$ at the age of 18.2 (SE 0.6) d, while it was higher $(P \leqslant 0.001), 14.8$ (SE 0.2) ng/ml, at 120.7 (SE 2.9) d (Fig. 1). During the $14 \mathrm{~h}$ light period, serum folates did not vary significantly and the patterns of these variations were similar for the two ages (interaction between time and age $P>0.05)$.

\section{Trial 2}

Body-weight, haemoglobin and packed cell volume values of heifers on days 0 and 10 of the experimental period are reported in Table 1.

Serum folates generally reached a maximum $1 \mathrm{~d}$ after the intramuscular injection of pteroylmonoglutamic acid (Fig. 2). The time response was analysed separately for both sides of the peak: days $0-1$ post-injection (positive slope) and days 1-10 post-injection (negative slope). The slope (absolute value) for the two sides of the peak increased linearly $(P \leqslant 0 \cdot 0001)$ whatever age with increasing amounts of injected pteroylmonoglutamic acid. Between days 0 and 1 post-injection, the response to pteroylmonoglutamic acid administration was different between the two age groups $(P \leqslant 0.0002)$ : the concentrations of serum folates of 2-week-old heifers increased dramatically from a mean value of 6.8 to 
Table 1. Trial 2*. Body-weight, haemoglobin and packed cell volume at days 0 and 10 post-injection for the two groups of heifers

(Mean values with their standard errors)

\begin{tabular}{|c|c|c|c|c|}
\hline \multirow[t]{2}{*}{ Age of heifers (d) ... } & \multicolumn{2}{|c|}{16.8} & \multicolumn{2}{|c|}{$126 \cdot 6$} \\
\hline & Mean & $\mathrm{SE}$ & Mean & $\mathrm{SE}$ \\
\hline \multicolumn{5}{|l|}{ Body-wt (kg) } \\
\hline Day 0 & $46 \cdot 7$ & $1 \cdot 1$ & $139 \cdot 5$ & $5 \cdot 4$ \\
\hline Day 10 & $51 \cdot 0$ & $1 \cdot 2$ & $148 \cdot 8$ & $6 \cdot 4$ \\
\hline \multicolumn{5}{|l|}{ Haemoglobin $(\mathrm{g} / \mathrm{l})$} \\
\hline Day 0 & 9.0 & $0 \cdot 4$ & $10 \cdot 3$ & $0 \cdot 1$ \\
\hline Day 10 & $8 \cdot 7$ & 0.4 & $10 \cdot 2$ & $0 \cdot 2$ \\
\hline \multicolumn{5}{|l|}{ Packed cell volume } \\
\hline Day 0 & $0 \cdot 31$ & 0.012 & $0 \cdot 34$ & $0 \cdot 004$ \\
\hline Day 10 & $0-29$ & 0.011 & $0 \cdot 32$ & 0.004 \\
\hline
\end{tabular}

* For details, see p. 596.
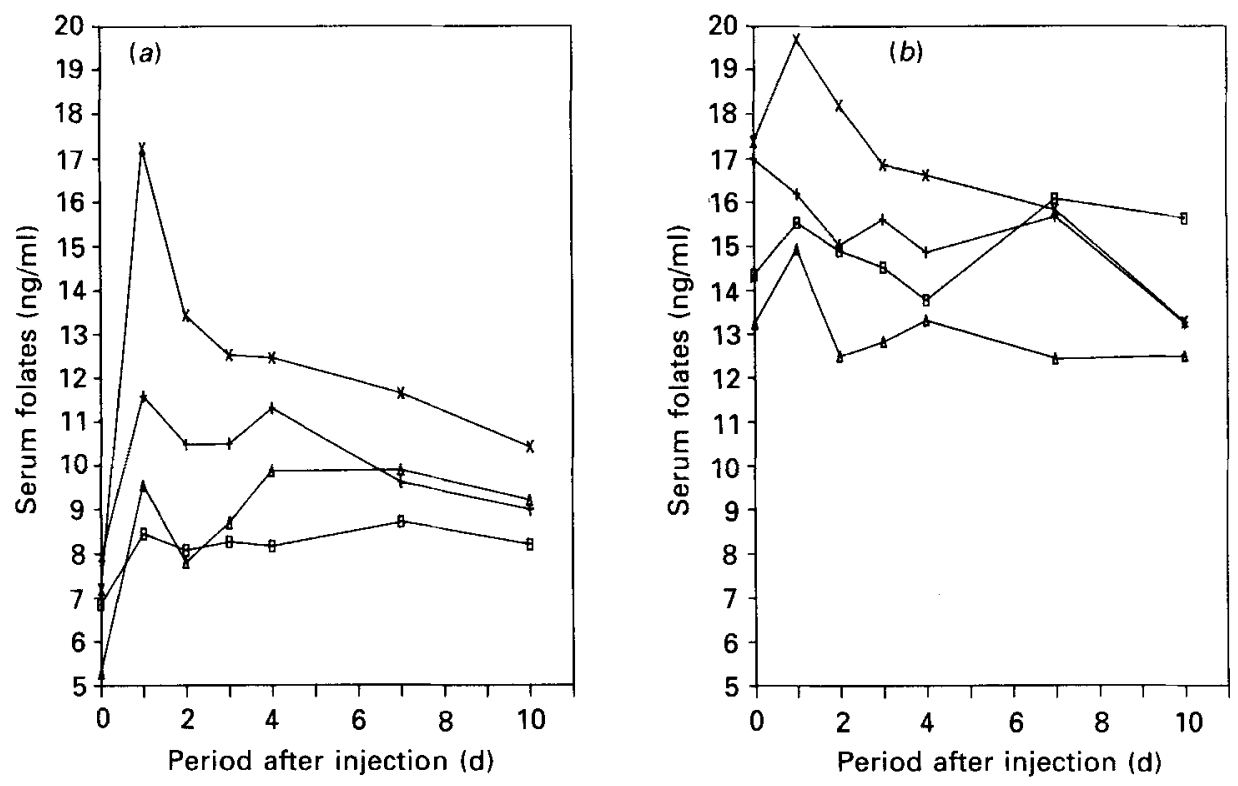

Fig. 2. Trial 2. Variations in concentration of serum folates of heifers aged $(a) 2$ weeks $(n 20)$ and $(b)$ 4 months $(n 20)$ after one intramuscular injection of $2.5(\square), 50(+), 100(\Delta)$ or $20.0(x) \mathrm{mg}$ pteroylmonoglutamic acid (SE 0.71). For details of procedure, see p. 596.

$11.7 \mathrm{ng} / \mathrm{ml}$, while in the 4-month-old heifers the effect of pteroylmonoglutamic acid administration was less marked (mean values 15.5 and $16.6 \mathrm{ng} / \mathrm{ml}$ ).

\section{DISCUSSION}

The concentrations of serum folates did not vary during the light period. Arbeiter \& Winding (1973) also observed some variations in serum concentrations of folates during the day for the adult bovine but these differences were not statistically significant. In our 
experiment the differences between the maximum and minimum were 1.69 and $1.33 \mathrm{ng} / \mathrm{ml}$ for the heifers aged 2 weeks and 4 months respectively. In spite of these small differences, in subsequent trials, blood samples were always taken at the same time of the day.

The concentration of serum folates in heifers aged 4 months was similar to the concentration reported for the adult bovine by Arbeiter \& Winding (1973) and Lorin (1980). However, in preruminant calves, the concentration of serum folates was lower than in the adult ruminant. Many authors reported that doubt remains concerning the efficiency of vitamin synthesis by rumen microflora during weaning and stabilization of rumen function (Kon \& Porter, 1954; Mornet \& Espinasse, 1977; National Research Council, 1978; Roy, 1980). Our hypothesis was that the difference between the two age groups might reflect a deficiency of folates in the younger animals.

In the second trial, an increase in concentrations of serum folates was observed after one intramuscular injection of pteroylmonoglutamic acid in the heifers of the two age groups. In the heifers aged 2 weeks, serum folates tended to increase to the pre-injection concentrations observed in heifers aged 4 months. This increase was less marked in heifers aged 4 months. The quantities of pteroylmonoglutamic acid on a per $\mathrm{kg}$ body-weight basis were different for the two age groups. This difference may explain the weak response of the older animals. However, if the quantities of pteroylmonoglutamic acid injected are calculated on a per $\mathrm{kg}$ metabolic live weight basis (i.e. per $\mathrm{kg}$ body-weight ${ }^{0.75}$ ), the doses were respectively $136 \cdot 7,279 \cdot 5,559.9$ and $1152.7 \mu \mathrm{g} / \mathrm{kg}$ body-weight ${ }^{0.75}$ for the 2 -week-old heifers and $54 \cdot 9,121 \cdot 9,260 \cdot 0$ and $496.2 \mu \mathrm{g} / \mathrm{kg}$ body-weight ${ }^{4 \cdot 75}$ for the heifers aged 4 months. The first three doses administered to heifers aged 2 weeks were comparable to the last three given to the older animals. In all cases, for a similar dose, the increase in concentration of serum folates after injection was higher for the younger animals than for the 4-month-old heifers (Fig. 2).

The weak response to intramuscular injection of pteroylmonoglutamic acid observed in heifers aged 4 months may also be explained by a rapid renal clearance of pteroylmonoglutamic acid, a water-soluble vitamin. Wagner (1985) reported that high blood concentrations of pteroylmonoglutamic acid would promote rapid renal excretion; as concentrations of serum folates are lower in the younger animals, renal clearance may be reduced. Moreover, in two treatments ( 5 and $20 \mathrm{mg}$ ), concentrations of serum folates at day 0 were equal or higher than $17 \mathrm{ng} / \mathrm{ml}$ in 4 -month-old heifers. In these animals, the serum concentration dropped $10 \mathrm{~d}$ after injection of pteroylmonoglutamic acid to a value lower than that before injection. In one of these treatments $(5 \mathrm{mg})$, serum concentrations of folates began to decrease the day after injection (Fig. 2). This decrease was due to one heifer whose concentration before injection, the highest in trial $2(26.75 \mathrm{ng} / \mathrm{ml})$, dropped to $8.86 \mathrm{ng} / \mathrm{ml}$ on day 1 . It seems that excretion of folates was accelerated after administration of pteroylmonoglutamic acid in the heifers with high concentrations of serum folates. In human beings, the concentration of unsaturated folate-binding proteins augments during pteroylmonoglutamic acid deficiency (Markkanen et al. 1972; Waxman, 1975). The same phenomenon might also explain the apparently higher retention time of folates in sera of heifers aged 2 weeks. Folate-binding proteins have been detected in bovine serum (Markkanen et al. 1974), but in adult cattle the plasma concentration of unsaturated folatebinding proteins is low (Mantzos et al. 1974). These proteins can deliver folates to the tissues and act as strong binders to protect folates against renal excretion (Fernandes-Costa \& Metz, 1979).

The marked response of concentrations of serum folates to an injection of pteroylmonoglutamic acid observed in heifers aged 2 weeks may be explained by the capture of folates by the serum folate-binding proteins or a slower renal clearance, or both. Further studies are necessary to elucidate the causes of the different response of the two age groups 
to the intramuscular injection of pteroylmonoglutamic acid and to evaluate the effects of a supplement of pteroylmonoglutamic acid on animal performances during the first months of life.

The authors are grateful to Mrs Chrystiane Plante, Michelle Guillette and Maryse Dumas for technical assistance. This work was partially subsidized by Hoffmann-La Roche Ltd, Basle, Switzerland.

\section{REFERENCES}

Agricultural Research Council (1980). The Nutrient Requirements of Ruminant Livestock. Slough : Commonwealth Agricultural Bureaux.

Arbeiter, K. \& Winding, W. (1973). Folatbestimmungen im Serum von Rindern mit besonderem Bezug auf die Fruchtbarkeit. Wiener Tierarzliche Monatsschrift 60, 323-326.

Cox, D. F. (1980). Design and analysis in nutritional and physiological experimentation. Journal of Dairy Science 63, 313-321.

Fernandes-Costa, F, \& Metz, J. (1979). Role of serum folate binders in the delivery of folate to tissues and to the fetus. British Journal of Haematology 41, 335-342.

Gill, J. L. (1978). Design and Analysis of Experiments in the Animal and Medical Sciences, vol. 1. Ames, Iowa: Iowa University Press.

Gill, J. L. \& Hafs, H. D. (1971). Analysis of repeated measurements of animals. Journal of Animal Science 33 , $331-336$.

Kon, S. K. \& Porter, J. W. G. (1954). The intestinal synthesis of vitamins in ruminants. Vitamins and Hormones 12, 53-68.

LeClercg, E. L., Leonard, H. W. \& Clark, A. G. (1966). Field Plot Technique. Minneapolis, MN: Burgess Publishing Co.

Lorin, D. (1980). Proceedings of the Second International Symposium of Veterinary Laboratory Diagnosticians, Lucerne, vol. 2, pp. 153-166.

Mantzos, J. D., Alevizoo-Terzaki, V. \& Gyftaki, E. (1974). Folate binding in animal plasma. Acta Haematologica 51, $204 \cdot 210$

Markkanen, T., Pajula, R.-L., Himanen, P. \& Virtanen, S. (1974). Binding of folic acid to serum proteins, IV. In some animals species. International Journal for Vitamin and Nutrition Research 44, 347-356.

Markkanen, T., Pajula, R.-L., Virtanen, S. \& Himanen, P. (1972). New carrier protein(s) of folic acid in human serum. Acta Haematologica 48, 145-150.

Mornet, P. \& Espinasse, J. (1977). Le Veau. Paris: Maloine S. A.

National Research Council (1978). Nutrient Requirements of Domestic Animals. no. 3, Nutrient Requirements of Dairy Cattle, 5th revised ed. Washington, DC: National Academy of Sciences.

Roy, J. H. B. (1980). The Calf, 4th ed. London: Butterworths.

SAS (1985). User's Guide. Cary, NC: Statistical Analysis System Institute Inc.

Snedecor, G. W. \& Cochran, W. G. (1971). Méthodes Statistiques, 6th ed. Paris: Association de Coordination Technique Agricole.

Wagner, C. (1985). Folate-binding proteins. Nutrition Reviews 43, 293-299.

Waxman, S. (1975). Folate binding proteins. British Journal of Haematology 29, 23-29. 